\title{
Chapter 3
}

\section{Photosynthesis in Global Cycle of Biospheric Carbon}

\author{
A.A. Ivlev \\ Additional information is available at the end of the chapter
}

http://dx.doi.org/10.5772/62222

\begin{abstract}
A key role of photosynthesis as a regulator of global carbon cycle dynamics is considered. According to the suggested model, global natural carbon cycle is regarded as a transition of carbon from the oxidative state, presented by carbon dioxide, bicarbonate, and carbonate species, into the reduced state, presented by different biogenic forms, produced in photosynthesis and in the following transformations. Photosynthesis provides a conversion of oxidative forms into reductive ones. The reverse transition is realized via respiration of living organisms, via microbial and chemical oxidations, accompanying transformations of "living" matter after burial. Among them the oxidation of the buried organic carbon by means of thermochemical sulfate reduction in the subduction zone, where lithospheric plates collide, is most important. Photosynthesis is under the impact of the Earth crust processes. In particular, the lithospheric plates' movement exerts the impact on photosynthesis development via periodic injections of $\mathrm{CO}_{2}$ into "atmosphere-hydrosphere" system during the plates' collisions. The irregular lithospheric plates' movement generates orogenic cycles which consist of short-term orogenic period of active volcanism, magmatism, and mountain building and a long-term geosynclynal period of low volcanic activity and quiet development of Earth crust processes. The pulsating movement of plates affects the dynamics and development of photosynthesis, which in turn determines the periodicity of numerous processes in the nature, including climatic cycles, changes in the rate of biodiversity, irregular accumulation of organic matter in sediments, uneven stratigraphic oil distribution, sea level changes, etc. The redox carbon cycle is a selforganizing system due to negative feedback between $\mathrm{CO}_{2}$ assimilation and photorespiration of global photosynthesis in response to oxygen growth. It made carbon cycle to shift to ecological compensation point. In this point, the system becomes sensitive to separate plates' collisions that results in short-term climatic oscillations.
\end{abstract}

Keywords: photosynthesis, $\mathrm{CO}_{2}$ assimilation, photorespiration, "greenhouse" and "icehouse" periods, biodiversity, global carbon cycle, plate tectonics, orogenic and geosynclynal periods of orogenic cycle, sedimentary carbonates, burial organic carbon 


\section{Introduction}

Here we concentrate one's attention on the unusual role of photosynthesis as a regulator of global carbon cycle dynamics. It stems from a new model of global natural carbon cycle which, despite the popular point of view, regards carbon turnover not only as a simple transfer of the element between different geospheres and biospheres but also as a transition of carbon from the oxidative state, presented by carbon dioxide, bicarbonate, and carbonate species, into the reduced state, presented by different biogenic forms, produced in photosynthesis and in subsequent transformations. That is why we named natural carbon turnover like a redox cycle of biospheric carbon. It has two branches - oxidative and reductive (Figure 1). The transition from oxidative species into reductive ones occurs by means of photosynthesis. The reverse transition is realized via respiration of living organisms, via microbial and chemical oxidations, accompanying transformations of "living" matter after burial. Among them, there is an oxidation of the buried organic carbon by means of thermochemical sulfate reduction occurring in the subduction zone, where lithospheric plates collide. This process is a dominant contributor to the oxidative branch of cycle.

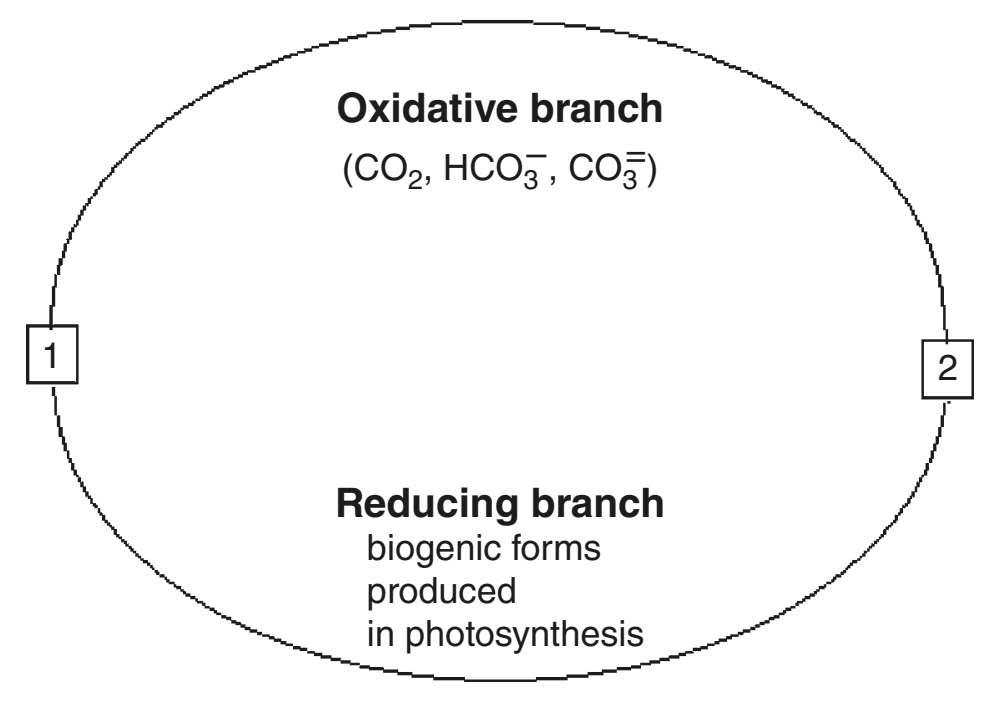

\section{Photosynthesis \\ 2 Respiration, oxidation of OM in subduction zone, and other oxidizing processes in the Earth crust}

Figure 1. Putative global carbon cycle in nature. Oxidative and reductive branches. The points of carbon transition from the oxidative states to the reduced ones (in photosynthesis) and back (in sulfate reduction in subduction zone). 
As early as 1926, a famous Russian geochemist V.I. Vernadsky put forward an idea on the interaction of biospheric and Earth crust processes [1]. This interpretation is as follows: photosynthesis developed under the impact of lithospheric plates' movement. The impact of lithospheric plates' movement on photosynthesis is transmitted via injections of $\mathrm{CO}_{2}$ arising in plate collisions with the participation of continental plates. In the course of these collisions under high temperatures arising in subduction zones, thermochemical sulfate reduction occurs resulting in the oxidation of sedimentary organic carbon. In the suggested scheme, the lithospheric plates' movement is an experimentally established fact, but the reason causing the movement is still arbitrary. A widespread hypothesis is that the movement results from magma convective motion which makes plates, covering magma surface, to move.

The carbon cycle spans different geospheres: atmosphere, hydrosphere, upper part of lithosphere, and biosphere. Prior to the origin of photosynthesis, the atmosphere was anoxic [2, 3], and the reduced carbon was mainly methane formed by archaebacteria [4]. The redox carbon cycle changed in parallel with the expansion of photosynthesis destroying most of the methane in the atmosphere. As photosynthesis expanded, oxygen concentration in the atmosphere reached such a high level, at which its concentration stabilized. At this point, the oscillatory regime was established, and the perturbations of carbon cycle in the form of short-term (tens of thousands years) "cooling-warming" transitions have appeared, expressed as the glacialinterglacial oscillations. Carbon cycle characteristics became sensitive to separate plates' collisions and to other factors.

In this study, the author uses the previously proven claim that photosynthesis is accompanied by two photosynthetic carbon isotope effects in $\mathrm{CO}_{2}$ assimilation and in photorespiration having opposite signs [5]. It gave him the opportunity, basing on the actualism principle, to use the differences in carbon isotope composition of sedimentary organic matter and that of coeval carbonates, as a delicate tool to investigate ${ }^{13} \mathrm{C}$ isotope discrimination in the past. It was used, in turn, to trace the climatic changes, the changes in the rate of biodiversity, to explain irregular accumulation of organic matter in sediments, uneven stratigraphic oil distribution, and many other phenomena.

\section{Two geological concepts supporting natural redox carbon cycle hypothesis. The suggested mechanism of the cycle functioning}

Two known geological concepts form the basis for the natural redox carbon cycle hypothesis. They are plate tectonics and orogenic cycles. The plate tectonics concept [6-8], or mobilism theory, asserts that the lithospheric plates, covering the entire Earth's surface, are in permanent motion. The motion is believed to occur due to convection of magma in the asthenosphere. Some researchers think that magma convection is a result of the impact of celestial bodies with the Earth's motion around the Sun [9]. Though the plate motion is an experimental fact, the real reason for the motion is still arbitrary. The motion is similar to the movement of an escalator. In some places of the Earth, in the zone of the mid-Atlantic ridge, where the crust is most subtle, magma erupts onto the surface and, coming into the contact with ocean water, 
hardens to form a new plate. It pushes other plates, causing their movement. In other places of the Earth (Wadati-Benioff-Zavaritsky zone) the plates, moving toward each other, collide. One of them, bending and moving down under the other, is absorbed by magma. The area where the collisions occur is called the subduction zone.

The orogenic cycle's concept was developed, in particular, by Rutten [2]. He studied the spatiotemporal distribution of sedimentary strata and concluded that the intensity of geological processes on the Earth over its geological history was unequal. There were relatively short periods, named orogenic periods, and the subsequent relatively extended periods of quiet development of the crust, named geosynclynal periods. The geosynclynal and the orogenic periods both constitute the orogenic cycle. According to Rutten's estimate, the duration of orogenic periods is about 50 million years, while that of geosynclynal periods amounts to several hundreds of millions years (up to 500 million years).

Orogenic periods are characterized by intensive mountain buildup and active volcanism, accompanied by volcanic eruptions and the entry of large masses of igneous rocks onto the Earth's surface. Geosynclynal periods correspond to the time of quiet Earth crust development and slow volcanic activity. It is the time for the accumulation of sediments and photosynthesis.

I took from Rutten his idea on orogenic cycle, and from the plate tectonic concept, I adopted the idea about plates' movement and plates' collisions. Combining both ideas and assuming that plates' movement was uneven, I have developed the following model.

In orogenic periods of the cycle, plates move rapidly and their collisions are frequent. Great quantities of volatile products, including $\mathrm{CO}_{2}$ and $\mathrm{H}_{2} \mathrm{~S}$, go onto the Earth surface from the subduction zone. In geosynclynal periods, the plates move slowly and the collisions are rare. Photosynthesis and weathering become the dominant processes. The collisions with the participation of the continental plates, bearing the sedimentary rocks with carbon in the form of carbonates and organic matter, are most interesting from the point of view of the natural redox carbon cycle.

During its life span, a continental plate accumulates sedimentary rocks with the buried organic matter and carbonates. When a plate descends and reaches the subduction zone, the rocks under high temperatures and great pressures are destroyed, but before they are absorbed by magma, the following reactions occur:

$$
\begin{aligned}
& \mathrm{MeCO}_{3}+\mathrm{SiO}_{2} \rightarrow \mathrm{MeSiO}_{3}+\mathrm{CO}_{2} \\
& \mathrm{MeCO}_{3} \rightarrow \mathrm{MeO}+\mathrm{CO}_{2}
\end{aligned}
$$

"Me" designates $\mathrm{Ca}^{2+}$ or $\mathrm{Mg}^{2+}$ cations.

These transformations do not change the redox state of carbon, and carbon transfer can be considered as a constant increment of the oxidative pool which does not affect carbon turnover.

The burial of organic matter and its transformation represent a different case. In thermochemical sulfate reduction, the organic matter reacts with evaporated sulfates according to the equation: 


$$
\mathrm{SO}_{4}{ }^{2-}+2\left(\mathrm{CH}_{2} \mathrm{O}\right) \Leftrightarrow 2 \mathrm{CO}_{2}+2 \mathrm{H}_{2} \mathrm{O}+\mathrm{S}^{2-}
$$

The resultant $\mathrm{CO}_{2}$, together with sulfides, is transferred from the subduction zones onto the Earth surface. This final step of oxidation completes the transfer of the reduced carbon into the oxidative forms. The above processes occur in the orogenic period.

On the Earth surface, due to chemical exchange reactions and in accordance with thermodynamics laws, $\mathrm{CO}_{2}$ is redistributed in the atmosphere and hydrosphere, composing the common "carbon dioxide-bicarbonate-carbonate" system:

$$
\mathrm{CO}_{2}(\text { gas }) \Leftrightarrow \mathrm{CO}_{2} \text { (dissolved) } \Leftrightarrow \mathrm{H}_{2} \mathrm{CO}_{3} \Leftrightarrow \mathrm{HCO}_{3}^{-} \Leftrightarrow \mathrm{CO}_{3}{ }^{2-}
$$

This system is close to equilibrium since the rate of chemical exchange is much greater than the rate of geological processes. The observed differences in carbon isotope composition of the atmospheric $\mathrm{CO}_{2}\left(\delta^{13} \mathrm{C} \approx-7 \%\right.$ o $)$ and of the carbonate species dissolved in seawater $\left(\delta^{13} \mathrm{C} \approx 0 \%\right.$ o $)$ evidence for the state close to equilibrium. In fact, the difference is about $5-7 \%$ o $[10,11]$, corresponding to the thermodynamic (equilibrium) values of isotope separation coefficients $\alpha\left(\mathrm{CO}_{2} / \mathrm{CO}_{3}{ }^{2-}\right)$ and $\alpha\left(\mathrm{CO}_{2} / \mathrm{HCO}_{3}{ }^{-}\right)$, which are equal to $1.005-1.008[10,12,13]$ and typical to Earth surface temperatures $\left(0-30^{\circ} \mathrm{C}\right)$.

Under the action of sunlight, photosynthesizing organisms absorb $\mathrm{CO}_{2}$ and water and convert the oxidized forms of carbon into the reduced ones, producing "living matter." After the conversion of the buried "living matter" into the sedimentary organic matter, the latter undergoes oxidation. Then all the processes repeat. This sequence of transformations forms a close loop.

All the above are depicted in Figure 2. In orogenic periods, shown as filled triangles, $\mathrm{CO}_{2}$ concentration in the system should increase abruptly because of frequent collisions of lithospheric plates when sedimentary rock masses fall in subduction zone and are destroyed with $\mathrm{CO}_{2}$ evolution. The entry of $\mathrm{CO}_{2}$ into the "atmosphere-hydrosphere" system leads to considerable growth of all oxidized carbon species in the system. Photosynthesis is stimulated by high $\mathrm{CO}_{2}$ concentrations achievable in the orogenic period. 


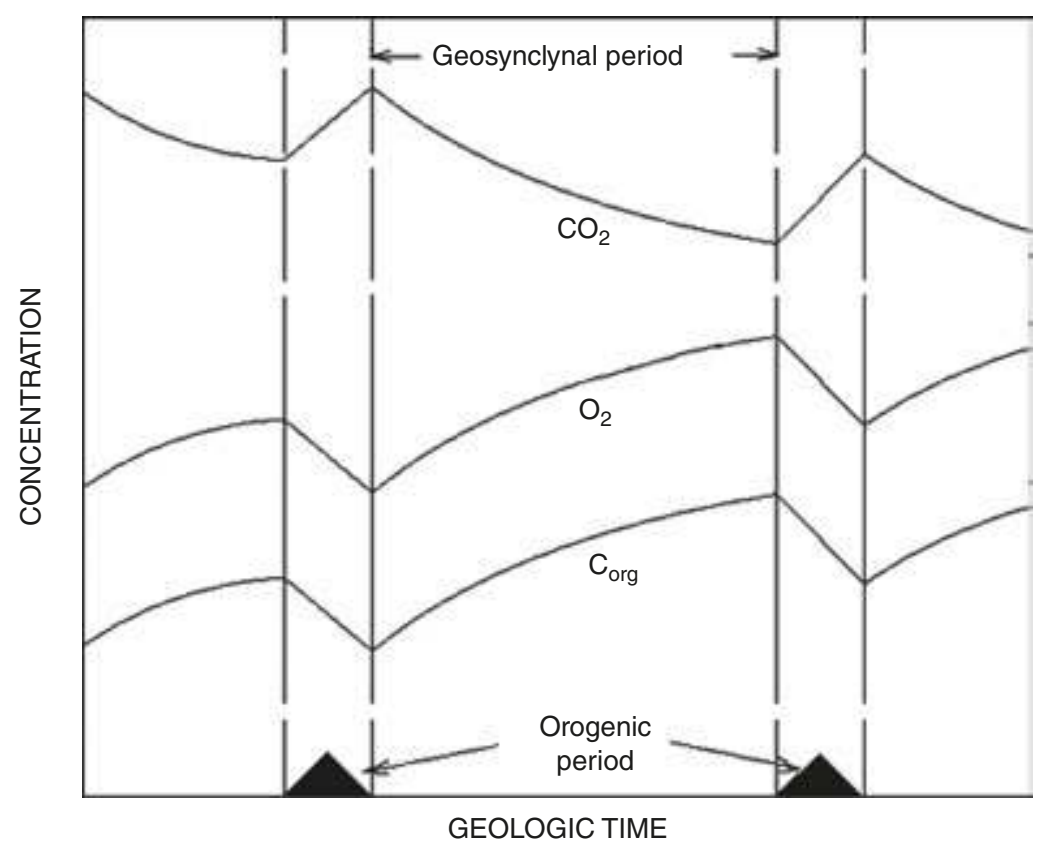

Figure 2. The scheme of the putative changes of $\mathrm{CO}_{2}$ and $\mathrm{O}_{2}$ in atmosphere and organic matter in sedimentary rocks in the course of orogenic cycles. Note that the variations of $\mathrm{CO}_{2}$ and $\mathrm{O}_{2}$ are in anti-phase, while the variations of $\mathrm{O}_{2}$ and organic matter are in phase.

At the same time, the atmospheric $\mathrm{O}_{2}$ concentration decreases since it is utilized in the oxidation of the reduced igneous rocks and reduced sulfur species, lifting from the subduction zones onto the Earth surface.

In the following relatively extended geosynclynal period, the rate of photosynthetic consumption of $\mathrm{CO}_{2}$ becomes greater than its emission from the subduction zones. It results in the depletion of the oxidative pool of carbon in the "atmosphere-hydrosphere" system. Onthe contrary the $\mathrm{O}_{2}$ concentration, due to photosynthesis, increases, achieving maximum concentration by the end of the geosynclynal period. The curve describing organic matter accumulation in sedimentary rocks in accordance with the global photosynthesis reaction hv

$\mathrm{CO}_{2}+\mathrm{H}_{2} \mathrm{O} \rightarrow \mathrm{CH}_{2} \mathrm{O}+\mathrm{O}_{2}$ coincides with the curve of $\mathrm{O}_{2}$ concentration, since the burial rate of organic matter changes in parallel with the growth of atmospheric oxygen concentration. Note that the atmospheric $\mathrm{CO}_{2}$ appears as a substrate, while the oxygen and the assimilated organic matter $\left(\mathrm{CH}_{2} \mathrm{O}\right.$ in this approximation) are the products of the global photosynthesis reaction.

Thus the model claims the periodic filling/depletion of "atmosphere-hydrosphere" system with $\mathrm{CO}_{2}$ and counter-phase parallel changes of $\mathrm{O}_{2}$. Accordingly, the periodic strengthening of $\mathrm{CO}_{2}$ assimilation and weakening of photorespiration should take place. In parallel with atmospheric $\mathrm{O}_{2}$ concentration changes, the accumulation of organic matter occurs in sedi- 
ments, since they are both the products of global photosynthesis. It means the periodic intensification of organic matter accumulation in sediments should take place.

Some important notes concerning carbon isotope fractionation in photosynthesis based on recent findings $[5,14]$ should be taken into account. The periodic depletion of carbon oxidative pool result in the appearance of carbon isotope Raleigh effect which affect the carbon isotope composition of sedimentary carbonates and organic matter displaying gradual ${ }^{13} \mathrm{C}$ enrichment with the extent of depletion. It allows examining orogenic cycles by means of the analysis of isotope composition of carbonate and organic carbon.

Following the actualism principle, one can take organic carbon as analog of "living" matter in the past, and coeval carbonates as analog of $\mathrm{CO}_{2}$, corresponding to that time. Then the isotopic difference between organic matter and carbonates should be regarded as analog of ${ }^{13} \mathrm{C}$ carbon isotope discrimination in modern plants. We denoted the above isotopic differences, after Popp et al. [15] and Hayes et al. [16] as $\varepsilon$ parameter. If so, in the orogenic period and at the beginning of the geosynclynal period when the $\mathrm{CO}_{2}$ concentration as well as the $\mathrm{CO}_{2} / \mathrm{O}_{2}$ concentration ratio in the environment are maximal, the ${ }^{12} \mathrm{C}$ enrichment of the organic carbon and $\varepsilon$ parameter should be maximal too.

By the end of geosynclynal period, when the $\mathrm{CO}_{2}$ and $\mathrm{CO}_{2} / \mathrm{O}_{2}$ concentration ratios are the lowest (photorespiration is maximal), the buried organic carbon should be the most enriched in ${ }^{13} \mathrm{C}$ (additional to Raleigh effect). Accordingly, the isotopic difference between organic matter and coeval carbonates should be minimal (Figure 3).

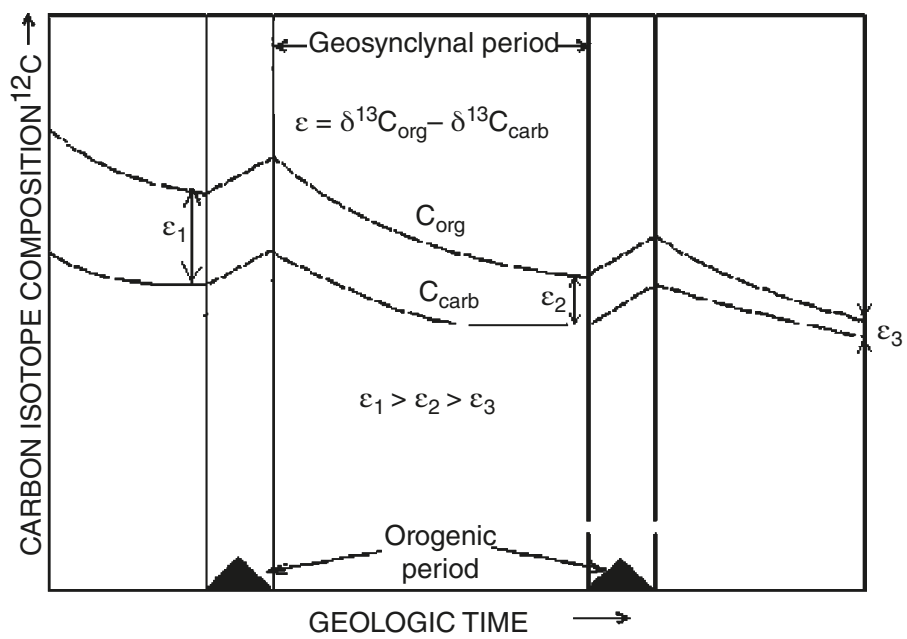

Figure 3. The scheme of putative changes of carbon isotope discrimination in photosynthesis $\varepsilon$ in the course of geological time; $\varepsilon$ is equal to carbon isotope difference between carbon isotope composition of sedimentary carbonates and coeval organic matter. The isotope discrimination decreases steadily with each subsequent cycle. 
The validity of the assertion can be seen from the measurements of the buried organic and coeval carbonates of different age [16]. They revealed noticeable differences in $\varepsilon$ parameter. In the Neoproterozoic era, from $1000 \mathrm{Ma}$ to $541 \mathrm{Ma}$, the isotope discrimination was found to be greater than $32 \%$. In the period from Cambrian to Jurassic, $\varepsilon$ changed to $28 \%$, and then in the period from Cretaceous to Late Cenozoic it was less than $28 \%$. They also noticed the successive growth of atmospheric $\mathrm{O}_{2}$ concentration from the Neoproterozoic to Late Cenozoic.

Thus the isotope technique provides an immensely effective and delicate tool for the orogenic cycle studies. This claim is supported by the fact that isotope ratios of organic carbon and coeval carbonates are the main and widely used factual materials in common geological studies.

\section{Isotope data support the idea on organic carbon oxidation in subduction zone during orogenic period}

The oxidation of organic carbon in subduction zone coupled with sulfate reduction during orogenic period is one of the critical points of the model that requires proof. According to [17], the natural sulfur cycle, like the carbon cycle, consists of the oxidative (sulfate) and reductive (sulfide) branches. To substantiate the above assertion, let us address the data from the work of Mackenzie and Piggot [17]. Temporal curves in Figure 4 demonstrate synchronous isotopic variations of carbon and sulfur of marine carbonates and gypsum (sulfates) in time.
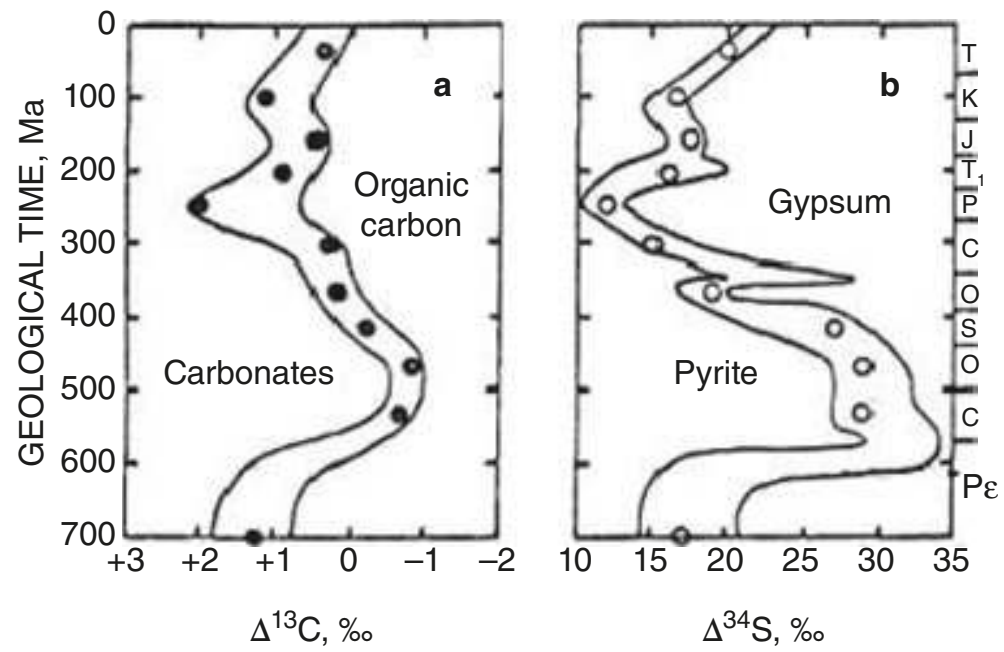

Figure 4. Coupling of global carbon and sulfur cycles. Synchronous variations of the curves of carbon isotope composition of carbonates (a) and sulfur isotope composition of sulfate sulfur in evaporates (b) for the last 700 million years in the geologic history of the Earth [17]. 
Such synchronism prompts itself that both cycles are somehow bound. Each curve has two differently directed humps. Next to them there are inscriptions, made by authors, to indicate minerals of sedimentary rocks that were mostly spread at the corresponding periods. Carbonates and pyrites correspond to the humps in lower parts of the curves. Organic matter and gypsum correspond to the humps in the upper part of the curves.

If we compare the above substances with the substrates and the products of sulfate reduction, it is easy to see that the substances corresponding to the lower humps on the curves coincide with the reaction products, and the substances corresponding to the upper humps on the curves coincide with the reaction substrates. The analysis of the isotopic changes of carbon and sulfur proves that the coincidence is not accidental.

By analyzing the dynamics of carbon and sulfur isotopic variations resulting from the curves on Figure 4, we should first note that the thermochemical sulfate reduction is followed by sulfur isotope fractionation $[18,19]$. Then, due to the periodic character of the reaction, the substrate is depleted. The depletion is followed by Raleigh effect. The more the reaction proceeds and the more the substrate pool is depleted, the greater the residual substrate (gypsum) is enriched with a "heavy" sulfur isotope ${ }^{34} \mathrm{~S}$. As it follows from the analysis of the lower part of the curves, the enrichment of gypsum with ${ }^{34} \mathrm{~S}$ is accompanied with the enrichment of carbonates with a "light" carbon isotope ${ }^{12} \mathrm{C}$. Both traits evidence in favor of high extent of sulfate conversion. Indeed, in the case of high extent of sulfate conversion, another reaction product $\mathrm{CO}_{2}$ should also be produced in a considerable amount. Thus the $\mathrm{CO}_{2}$ inherits "light" carbon isotope composition from organic matter. Hence, when "light" $\mathrm{CO}_{2}$ enters marine "carbon dioxide-carbonate" system with carbon enriched in ${ }^{13} \mathrm{C}$, it makes carbon in the system "lighter" due to chemical isotope exchange.

A quite opposite scenario can be deduced from the analysis of the upper parts of the curves. The ${ }^{32} \mathrm{~S}$ enrichment of gypsum evidences that the extent of sulfate conversion is low. Hence small amounts of "light" $\mathrm{CO}_{2}$ are produced, and marine carbonates become "heavier" as compared with the previous case. Thus, the coupled isotopic changes of carbon and sulfur of marine carbonates and gypsum, in addition to chemical arguments, give firm proofs that they represent the results of sulfate reduction process occurring in the subduction zones.

An indirect argument in favor of sulfate reduction in subduction zone was the great abundance of sulfide-oxidizing bacteria in the Precambrian. It evidences for significant inflow of the reduced sulfur forms (sulfides and hydrogen sulfide) onto the Earth surface. This was favored by low oxygen concentration in the Earth's atmosphere at that time. The sulfide-oxidizing bacteria were so widely disseminated that gave grounds for Hayes et al. [16] to conclude that these bacteria were the main source of organic matter in rocks in the Proterozoic.

Thus, the coupled isotopic changes of carbon and sulfur of marine carbonates and gypsum, in addition to chemical and paleontological arguments, give firm proofs that they represent the results of sulfate reduction process occurring in the subduction zones. 


\section{The effect of redox carbon cycle on the climate in the past}

The role of $\mathrm{CO}_{2}$ in climate formation is a well-known fact. It is the main component of "greenhouse" gases [20]. The periodic filling of the "atmosphere-hydrosphere" system with $\mathrm{CO}_{2}$ in orogenic time and the following depletion of $\mathrm{CO}_{2}$ due to photosynthetic assimilation in geosynclynal period provide alternating warming-cooling change. It is even possible to use the relation between $\mathrm{CO}_{2}$ concentrations and Earth temperature for the determination of paleotemperatures [21], although the validity of this correlation is limited due to the contribution of other greenhouse gases.

Following the logic of this model, the existence of climatic cycles is a result of the orogenic cycles. The beginning of the orogenic cycle may be considered as the warmest time of the cycle and the end as the coldest one. The latter is often accompanied with glaciations.

The mentioned $\varepsilon$ parameter may be used as the indicator of orogenic and climatic cycles. At the beginning of the orogenic cycle, when $\mathrm{CO}_{2} / \mathrm{O}_{2}$ ratio is maximal and the contribution of photorespiration is low, $\varepsilon$ parameter is also at its maximum and corresponds to the warming period. Conversely, at the end of the cycle, when $\mathrm{CO}_{2} / \mathrm{O}_{2}$ ratio is minimal and photorespiration increases, $\varepsilon$ parameter reaches its minimum and corresponds to the cooling period.

Popp et al. [15] found a coherence of $\varepsilon$ values and climatic cycles in the Cenozoic. Hayes and others [16], having examined carbon isotope composition for more than 5000 samples of coeval carbonates and sedimentary organic matter spanning the Precambrian and Phanerozoic, found statistically significant differences in $\varepsilon$ values in interglacial periods and those in periods of glaciations. The results were supported by other researchers [22, 23].

\section{The impact of redox carbon cycle on the rate of biodiversity}

It is a known fact in geological history that in the past there were "explosions" of life and mass extinctions of living organisms. In some works, a periodicity in a rate of change of biodiversity (a rate of appearance of the new fauna and flora species per geological unit) in time was revealed [24]. Following the redox carbon cycle model, these facts can be reasonably explained. It was supposed that periodicity is caused by the increase of oxygen concentration in the Phanerozoic atmosphere [25]. The assumption was supported by a close coherence of the curves illustrating the time dependence of a rate of change of biodiversity and other parameters, strongly related with oxygen concentrations. The peaks of all curves fully coincided and corresponded to oxygen maximum (see Figure 7 from [25])

The physical sense of this link is quite clear. The elevated $\mathrm{O}_{2}$ concentrations in the atmosphere stimulate (photo)respiration in photosynthesizing organisms, which is followed by superoxide radical formation. They attack gene molecules causing mutations. Though in a cell there are some enzymes, which destroy radicals reducing them to $\mathrm{H}_{2} \mathrm{O}$ and $\mathrm{O}_{2}$, at the time of oxygen growth, the enzymes fail to cope with the abundance of radicals and to diminish their amount to the safe level. As a result, mutations appear and the rate of change of biodiversity increases. 
Rothman [26] found a good correlation of $\varepsilon$ parameter and the rate of change of biodiversity for land plant families as well as for marine animals. His results prove the relation of orogenic cycles and biodiversity rate.

The observed periodicity of mass extinctions of plant and animal species on the Earth has a close agreement with the previous correlation. These events are also linked with a change of $\mathrm{CO}_{2} / \mathrm{O}_{2}$ ratio in the atmosphere over time [27]. According to the model, the abrupt change of $\mathrm{CO}_{2} / \mathrm{O}_{2}$ ratio in the atmosphere occurring in orogenic cycles' transitions should lead to the extinction events, because they are followed by the change of aerobic conditions to anoxic ones causing a mass extinction of aerobic organisms.

\section{Irregular periodicity in organic carbon accumulation in sediments is the reason for uneven stratigraphic distribution of sediments rich in organic matter and oils}

It stems from the model's logic that there should be uneven rate of organic matter accumulation in sediments as a result of $\mathrm{CO}_{2}$ variations in the course of orogenic cycles. In the orogenic periods of the repeated cycles, the "atmosphere-hydrosphere" system of the Earth is filled with $\mathrm{CO}_{2}$, coming from the subduction zone. In the subsequent geosynclynal periods, due to a dominant role of photosynthesis, the system is gradually depleted in the oxidized carbon species. It means that the photosynthesis rate is maximal at the beginning of the cycle and reaches its minimum by the end. The opposite scenario could be expected for organic matter accumulation in sediments. The maximum of organic matter accumulation should take place by the end of the cycle, when most of the $\mathrm{CO}_{2}$, that entered the "atmosphere-hydrosphere" system in the orogenic period, after some transformation is converted into organic matter. As a result, the uneven stratigraphic distribution of sediments rich in organic matter appears. The other consequence of the uneven stratigraphic distribution is the irregular distribution of the oils generated by these sediments.

Though the kinetics of global photosynthesis and organic matter accumulation is unknown, we assumed that the mentioned kinetics is described by the simplest first-order equation. It corresponds to proportional, in-phase of $\mathrm{O}_{2}$ and buried organic carbon variations (Figure 5), and anti-phase atmospheric $\mathrm{CO}_{2}$ and $\mathrm{O}_{2}$ variations (see Figure 1 from [25]). The corresponding curves, depicting the behavior of $\mathrm{CO}_{2}$ and $\mathrm{O}_{2}$ in the atmosphere and organic matter in sedimentary rocks obtained in climatic and depositional models, are in full agreement with the changes expected from the proposed carbon cycle model. 

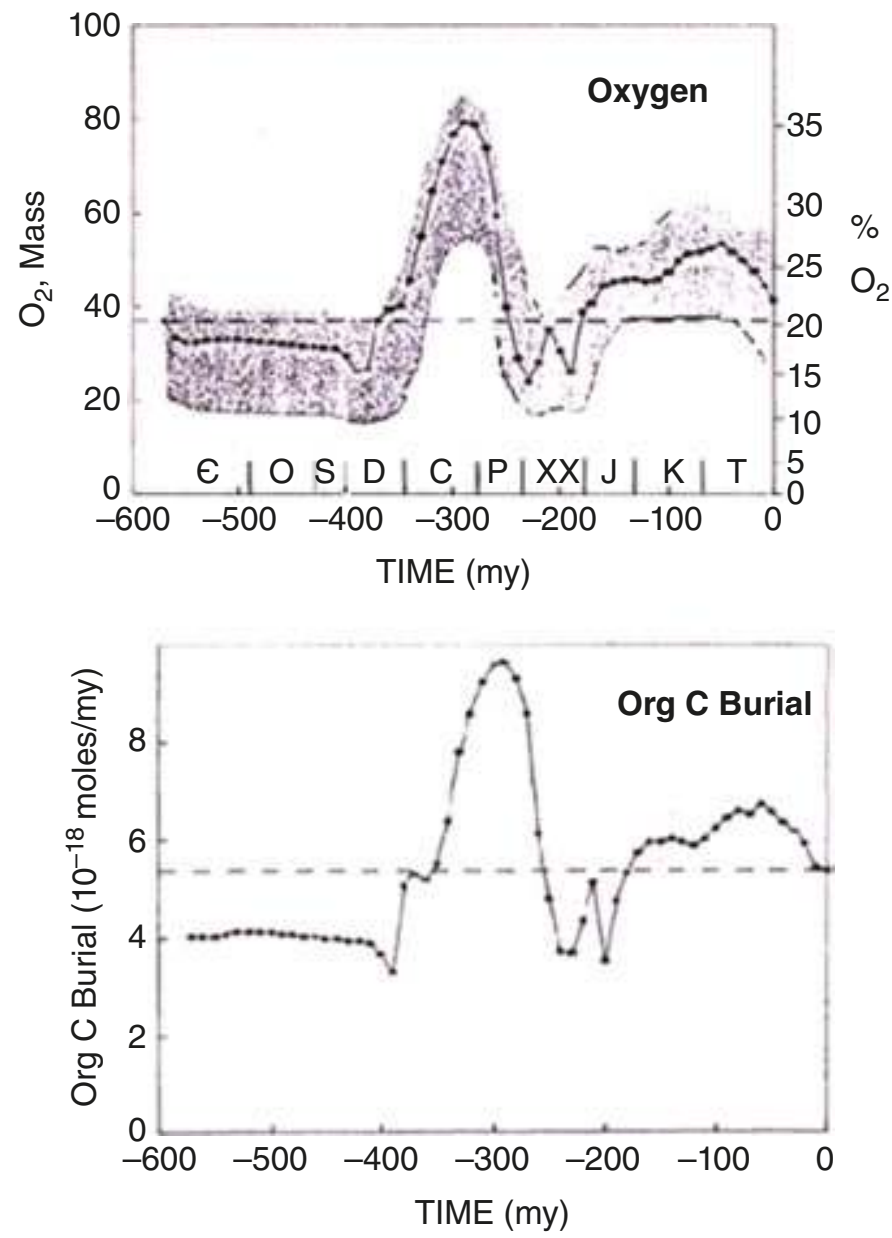

Figure 5. The in-phase changes of oxygen content in the atmosphere and burial organic matter rates in the sedimentary rocks in the Phanerozoic. The shaded zone for oxygen designates the zone of possible errors based on sensitivity analysis [29].

In fact, Bazhenova and Sokolov [28], examining the stratigraphic distribution of Domanic oil source rocks, revealed that these sediments rich in organic matter were present in different continents at the same stratigraphic levels. They are found practically in all systems of the Phanerozoic and of the Precambrian. The stratigraphic levels, where domanicoids were fixed, are Ediacaran-Cambrian, Devonian-Carboniferous, and Late Jurassic-Early Cretaceous. Such nonuniform stratigraphic distribution can be explained in the frames of the natural redox carbon cycle dynamics.

The formation of sediments rich in organic matter is likely bound to the transitions from one cycle to another when there was a change of aerobic conditions to anoxic causing mass 
extinction of living organisms. Their biomass is a probable source of organic material. The repeatability of orogenic cycles determines the appearance of domanicoids at different stratigraphic levels in the Precambrian and the Phanerozoic.

Though the periods, indicated by Bazhenova and Sokolov [28], are rather conditional, they are known to include glacial periods. During the Ediacaran period, there were Varanger (660 to $635 \mathrm{Ma}$ ) and Gaskiers (590 to $575 \mathrm{Ma}$ ) glaciations; in Devonian, there was the Andean-Saharan (ca. $440 \mathrm{Ma}$ ) and then Permo-Carboniferous (320 Ma) glaciations; in Late Jurassic-Early Cretaceous period, traces of glaciations were not found with certainty, but there was a great extinction (66 Ma), which was caused by a bolide impact. Besides this, the indicated time was characterized by high oxygen concentration likely associated with glaciations and land life development. It should be stressed that Bazhenova and Sokolov [28] marked that periods of organic matter accumulation were followed by rifting process which in accordance with our model corresponds to the orogenic period, occurring behind the cooling time.

It is natural to consider that Domanic oil source rocks as well as other rocks rich in organic matter ("black" shales) are oil kitchen. Therefore, the periods of oil source rock - formation should be related to oil generation, and one could expect that the oil field discoveries are mostly related with this time with high probability. This assertion is supported by the available data. Figure 6 illustrates the stratigraphic distribution of the discovered oil fields in the world [30] and the distribution of oil fields in the former USSR [31]. The latter is presented as a ratio of number of oil fields for a given period to the total number of oil fields [Figure 6b]. As it can be seen, in both cases the distributions are very similar and irregular. Though the comparison is not very strict, Figure 6b, unlike Figure 6a, does not take into account the sizes of oil fields, nevertheless the comparison is still reasonable. The peaks in both distributions correspond to each other; the number of the peaks is the same. According to both distributions, the beginning of oil generation falls in time limits from 600 to 500 million years ago. This is in agreement with the considerable growth of oxygen concentration in the atmosphere. As it was noted, oxygen concentration is an indicator of organic matter accumulation in sediments. According to some data [32, 33], one can accept that in most of the Precambrian, oxygen concentration was less than $1 \%$, and only by the end of the Precambrian it started to increase significantly [34]. It is logical to assume that photosynthesis needs a prolonged time to accumulate the amount of organic matter in sediments sufficient to produce hydrocarbons capable to form oil fields. One can follow it by tracing the $\mathrm{O}_{2}$ concentration in the atmosphere. 

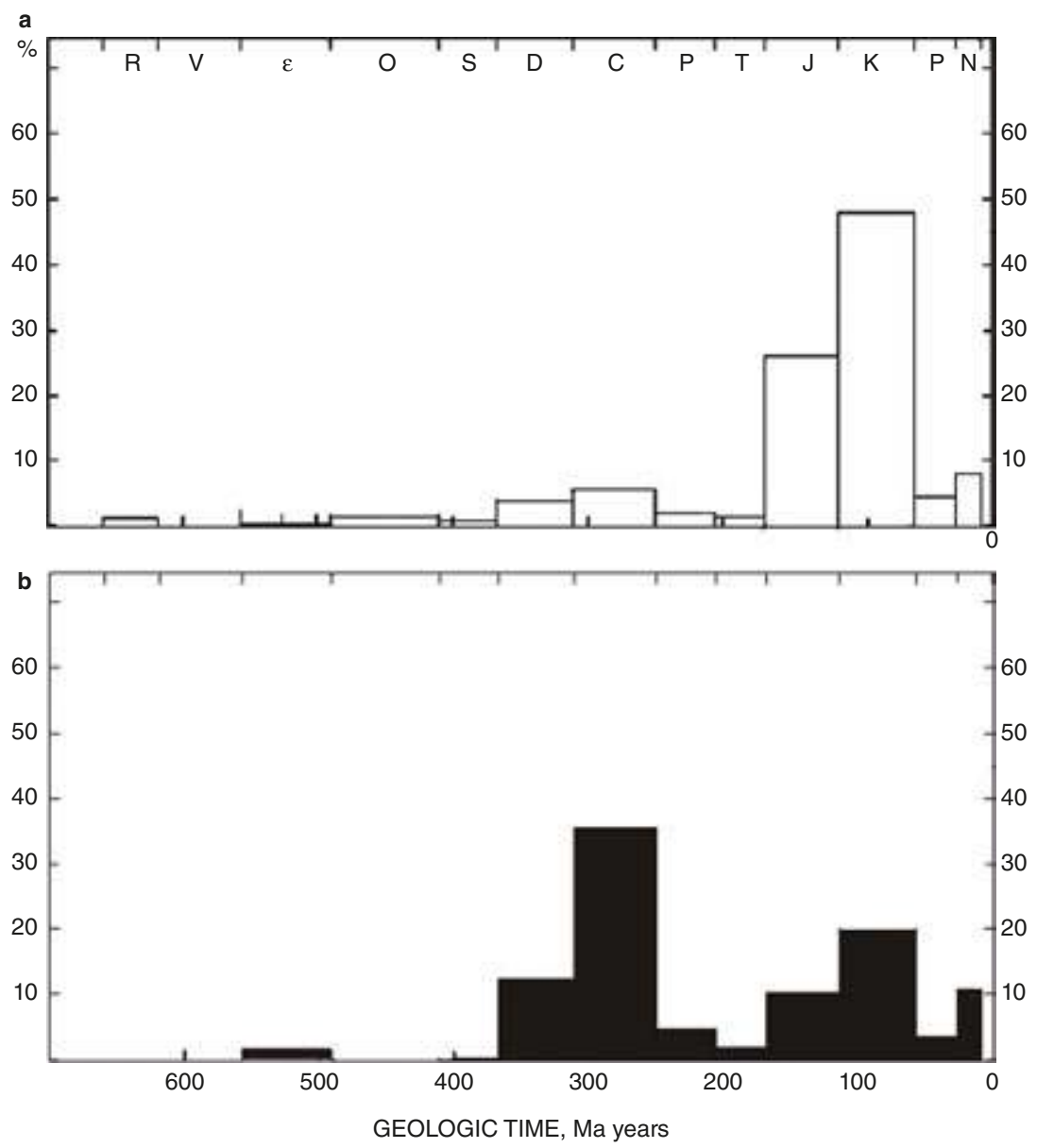

Figure 6. Comparison of distribution of explored extractable oil fields in the largest world reservoirs (Vishemirsky, Kontorovich, 1997) [30] (a) and revealed oil fields (\% of the total number of oil fields) of the former USSR (Korchagin, 2001) [31] (b) with stratigraphic subdivisions.

\section{7. ${ }^{13} \mathrm{C}$ enrichment of oils reflects $\mathrm{O}_{2}$ growth in the atmosphere and display four orogenic cycles from the Cryogenian period of Neoproterozoic era to the Miocene epoch of Cenozoic era}

Having examined the extensive collection of oils (504 oil samples) differing in age and origin, Andrusevich et al. $[35,36]$ established that in the course of geological time, the oils and their components have been consistently enriched in ${ }^{13} \mathrm{C}$ (Figure 7). Model's logic allows concluding that the most likely reason for this enrichment is the intensified photorespiration of photo- 
synthesizing organisms as a result of the increase of average oxygen concentration in the atmosphere. One should take into account that, despite of variations, in the course of geological time; an average atmospheric oxygen concentration steadily grew up. The ${ }^{13} \mathrm{C}$ enrichment of oils reflects that at least four orogenic cycles took place, accompanied by an increase in average oxygen concentration in the atmosphere. Oils inherit the enrichment from organic matter. The existence of four orogenic cycles in Phanerozoic agrees with the other proofs (see the previous section), evidencing for four waves of oil generation in the Phanerozoic.

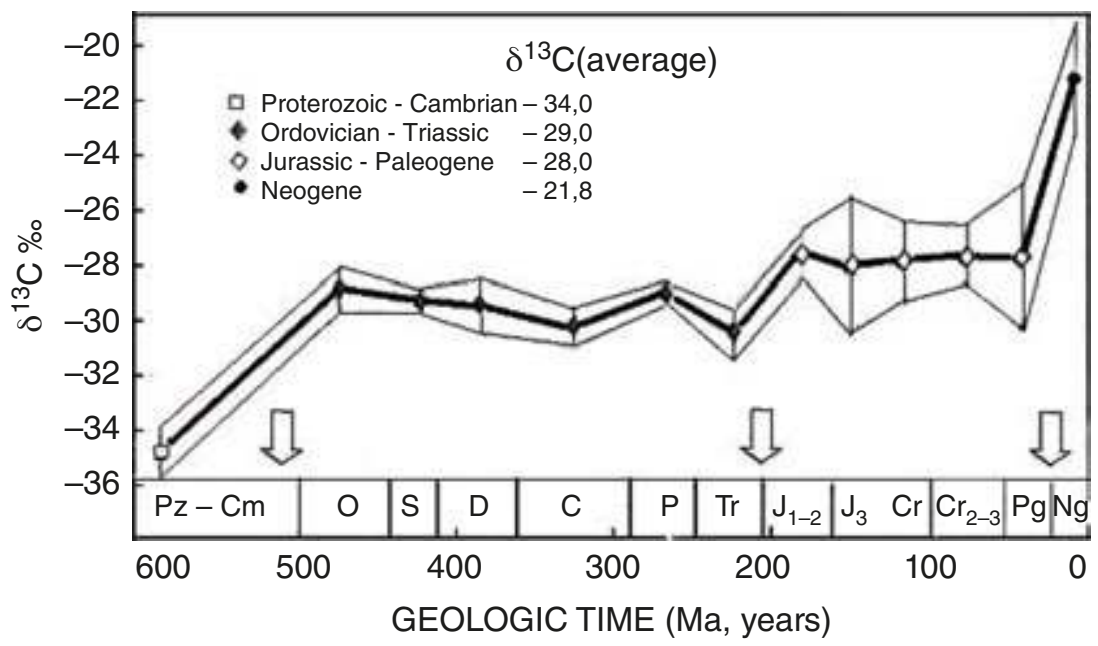

Figure 7. Change of the average carbon isotope composition $\left(\delta^{13} \mathrm{C}, \%\right)$ for saturate fraction $\mathrm{C}_{15+}$ of crude oils. Vertical bars are standard deviations, which increase with decreasing age. Arrows indicate Cambrian-Ordovician, Triassic-Jurassic, and Paleogene- Neogene boundaries where ${ }^{13} \mathrm{C}$ enrichment occurs [36].

One more interesting observation indicating the validity of the model stems from the analysis of the above data. Since Jurassic, a scatter in carbon isotopic composition of oils has increased essentially. The variety of land photosynthesis conditions resulted in a wide spectra of $\delta^{13} \mathrm{C}$ values.

\section{Ecological compensation point}

Global natural redox carbon cycle is a developing and self-organizing system. This feature is provided due to photosynthesis which is an essential part of the cycle. Its origin occurred in anoxic atmosphere. The photosynthesis evolution was followed by atmospheric oxygen growth. The literature data, given below, illustrate oxygen growth in the atmosphere over geological time. Atmospheric $\mathrm{O}_{2}$ concentration prior to photosynthesis was determined by water dissociation under ultraviolet action and was equal to one thousandth part of the present oxygen level (Urey level). With the emergence of photosynthesis, the average oxygen concentration in the atmosphere began to increase from cycle to cycle. 
The Early Archean oxygen concentration was up to 0.02-0.08\% (Urey's level) (Rutten, 1971) [2]. From the Late Archean (3.0-2.7 Ga) to Middle Proterozoic (2.2-2.0 Ga) oxygen concentration reached $0.21 \%$ (Pasteur's level) [2, 32, 33]. In the Neoproterozoic (Tonian- CryogenianEdiacaran, 1000-550 Ma), oxygen concentration was estimated to be up to $5 \%$, reaching $8 \%$ in the end of Ediacaran [34]. In the Early Paleozoic (Cambrian, 541-485 Ma), according to different estimates, oxygen concentration was 12-13\% [29, 37, 38]. In the Middle Paleozoic (OrdovicianSilurian, 485-420 Ma), oxygen concentration has been 13-15\% [39]. In the Late Paleozoic (Carboniferous-Early Permian, 350-280 Ma), oxygen concentration reached about 30-35\% [37, 38]. In the Early Mesozoic (Triassic) (250-200 Ma), oxygen concentration has reduced down to $15-17 \%[39,40]$. In the Miocene epoch of Neogene (23-5 Ma), oxygen content again increased to $25 \%$ level [41].

The oxygen growth is explained by photosynthesis expansion. In parallel, another product of global photosynthesis, "the living matter," transforming into "buried organic matter," was accumulated in sedimentary rocks. How long could it last? As free oxygen accumulated in the atmosphere, photosynthesizing organisms have acquired photorespiration which was in reciprocal relations with $\mathrm{CO}_{2}$ uptake [42]. As known, carbon dioxide uptake increases biomass production, whereas photorespiration reduces it. As a result, photorespiration decreased the expansion of photosynthesis and brought down the accumulation of buried organic matter. Despite the absolute growth of buried organic matter in sediments, its relative input became lesser with each new orogenic cycle. The contribution of the above processes to metabolism depends on the $\mathrm{CO}_{2} / \mathrm{O}_{2}$ ratio in the environment. The latter ratio steadily grew down in the course of orogenic cycles. Thus photosynthesis performed a regulatory role in carbon cycle.

For individual photosynthesizing organisms of $\mathrm{C}_{3}$-type, which were the first representatives of photosynthesizing life on the Earth, a term "compensation point" is applicable. It is a metabolic state of the organism at a particular concentration ratio of $\mathrm{CO}_{2}$ and $\mathrm{O}_{2}$ when $\mathrm{CO}_{2}$ uptake becomes equal to $\mathrm{CO}_{2}$ release. Below this point, the rate of photorespiration (together with respiration) exceeds the rate of photoassimilation, and the physiological existence of organisms becomes impossible. As $\mathrm{CO}_{2}$ and $\mathrm{O}_{2}$ are mutually related, the compensation point may be determined via consideration of either $\mathrm{CO}_{2}$ or $\mathrm{O}_{2}$ concentrations [43].

It was shown that the plants placed in a closed chamber due to reverse links (reciprocal relations) between main photosynthetic processes, $\mathrm{CO}_{2}$ assimilation and photorespiration, make the $\mathrm{CO}_{2} / \mathrm{O}_{2}$ ratio in chamber atmosphere stable $[43,44]$. Considering these results, Tolbert et al. [43] assumed that the same feedback mechanism acts in nature and is responsible for the achievement of stationary $\mathrm{CO}_{2}$ and $\mathrm{O}_{2}$ concentrations in the atmosphere. They introduced the term "ecological compensation point." The above processes are the driving forces in achieving the ecological compensation point. The numerous oxidation processes of the reductive branch, due to $\mathrm{O}_{2}$ consumption and $\mathrm{CO}_{2}$ evolution, play a regulatory role via common reaction intermediates, defining the real position (concentrations) of the ecological compensation point. In this position, the full conversion of the reduced carbon into the oxidized forms and back occurs. The total interaction of $\mathrm{CO}_{2}$ assimilation and photorespiration provides the excess of reductive carbon over oxidative in period from photosynthesis origin up to the moment of achieving the ecological compensation point. The excess of the reduced carbon was accumu- 
lated in deposits in the form of buried organic matter. The corresponding amount of oxygen was accumulated in the atmosphere.

The glacial-interglacial oscillations of $\mathrm{CO}_{2}$ have emerged as a consequence of proximity of the system to the ecological compensation point [22,45-48]. This possibly happened in the end of Carboniferous when the great expansion of photosynthesis took place and covered the land [49]. The ecological compensation point was most likely achieved in the Neogene (Miocene). At this time, after some decline, there was a burst of atmospheric oxygen to the maximum level associated with global cooling. Right after cooling in the Miocene, there was considerable warming in the Pliocene period [50-52]. The warming was followed by mass extinction of organisms, and by the formation of sediments rich in organic matter. These sequences of climatic changes are characteristic of transitions from one orogenic cycle to another.

After achieving the ecological compensation point, global carbon cycle became very sensitive to separate plates' collisions, what is in agreement with short-term glacial-interglacial oscillations of $\mathrm{CO}_{2}$. It allows assuming that long-term orogenic cycles and short-term oscillations have the same physical nature.

The most important conclusion from the existence of the ecological compensation point is the following. After the achievement of ecological compensation point, the system of global carbon cycle gets its stationary level. No additional accumulation of buried organic carbon occurs. It means no additional oil generation takes place, and hence the amount of oil in the Earth crust becomes stable and limited. Hence it should be concluded if the rate of oil production is greater than the rate of generation, oil resources should be exhausted with time.

\section{Conclusions}

New redox carbon cycle model is suggested. It claims a dominant role of photosynthesis in the mechanism of cycle functioning. According to the model, carbon transfer between geospheres and biosphere is accompanied by the changes in the redox state of carbon. Photosynthesis provides the transfer of carbon from the oxidative to the reduced state. The reverse transfer takes place in numerous processes of oxidation, including the respiration of living organisms and the processes of direct and indirect oxidation of buried organic matter. The final powerful oxidation of organic matter occurs in sulfate reduction proceeding in the subduction zones (plates' collisions zone).

Photosynthesis connects the Earth crust and biosphere processes. This link is realized by means of $\mathrm{CO}_{2}$ pulses appearing in lithospheric plates' collisions when they move. The source of $\mathrm{CO}_{2}$ is the oxidation of the buried organic matter in sulfate reduction in subduction zone. The last reaction is the coupling point of natural carbon and sulfur cycles.

Lithospheric plates' movement has two phases. In the short-term orogenic phase, the $\mathrm{CO}_{2}$ coming from subduction zone fills the "atmosphere-hydrosphere" system, causing climate warming. In the long-term geosynclynal phase, weathering and photosynthesis become dominant processes, depleting the oxidative forms of carbon followed by glaciations. By this 
way, photosynthesis transmits the impact of Earth crust processes on biosphere. The irregular periodicity exerts an impact on climate, biodiversity, distribution of organic matter in sedimentary deposits, etc.

Thus due to the unique combination of $\mathrm{CO}_{2}$ assimilation and photorespiration, which are in reciprocal relations, photosynthesis plays a key regulatory role in the carbon cycle. During photosynthesis, the expansion of $\mathrm{O}_{2}$ concentration in the environment permanently grew while that of $\mathrm{CO}_{2}$ dropped. When they reached values limiting physiological boundaries of life, the changes ceased and the $\mathrm{CO}_{2} / \mathrm{O}_{2}$ ratio became stable. This state does correspond to ecological compensation point. In terms of global photosynthesis, it means that all biomass, produced by photosynthesis, is oxidized in numerous processes of respiration, microbial and chemical oxidation in sediments. It happened when photosynthesis had spread over the whole land. The last splash of oxygen in the atmosphere occurred in the Miocene.

Prior to this moment, the excess of photosynthesis production was accumulated in sediments as a buried organic carbon. Thus, the process of organic carbon accumulation in sediments went on from the origin of photosynthesis up to the ecological compensation point.

On achieving the ecological compensation point, further accumulation of buried organic carbon has ceased. The amount of organic matter and its derivatives in sediments became stationary. It means that the amount of oils generated by source rocks also stabilized.

It should be underlined that the isotope techniques now are a powerful instrument of examination of the processes in the past. It became possible since in many cases carbon isotopic discrepancies remain unchangeable and preserve its memory about the processes. Among them, carbon isotope technique is of special interest. In accordance with actualism principle, carbon isotopic difference between carbonate and coeval organic matter ( $\varepsilon$ parameter) is the analog of ${ }^{13} \mathrm{C}$ isotope discrimination in modern plants, while $\varepsilon$ parameter is a function of $\mathrm{CO}_{2} /$ $\mathrm{O}_{2}$ ratio in the environment. Moreover, the above isotopic differences are the most widely used data in geology studies. The established changes of the $\mathrm{CO}_{2} / \mathrm{O}_{2}$ ratio, found by means of carbon isotope data, reflect many events of evolution of the atmosphere, climate, and other coupled phenomena in the biosphere. Combining this technique with adequate carbon cycle model, researchers obtain a very delicate tool to study various phenomena in the past, including evolution itself. Very interesting and important results can be obtained in combination of isotopic techniques of different elements.

\section{Author details}

A.A. Ivlev

Russian State Agrarian University - Moscow Agricultural Academy of K.A. Timiryazev, Russian Federation 


\section{References}

[1] Vernadsky V.I. The Biosphere.1926ed.Complete Annotated Edition:Copernicus Books; New York. 1986.

[2] Rutten M.G. The Origin of Life by Natural Causes: Elsevier; Amsterdam. 1971.

[3] Farquhar G.D., Zerkle A.L., Bekker A. Geological constraints on the origin of oxygenic photosynthesis. Photosynth. Res. 2011. 107: 11-36.

[4] Schrag D.P., Higgins J.A., Macdonald F.A., Johnston D.T. Authigenic carbonate and the history of the global carbon cycle. Science 2013. 339: 540-543.

[5] Ivlev A.A. Oscillatory nature of metabolism and carbon isotope distribution in photosynthesizing cells. In: Najafpour M.M, editor. Photosynthesis - fundamental aspects: Intech Publishers; Croatia. 2012. pp. 341-366.

[6] Wegener A. Die Entstehung der Kontinente und Ozeane (4 ed.): Friedrich Vieweg \& Sohn; Akt. Ges., Braunschweig. 1929.

[7] Flint R.F. The Earth and Its History: J. Wiley \& Sons; New York. 1973. 354 p.

[8] Monin A.S. Istoriya Zemli [History of the Earth]: Nauka; Leningrad. 1977. 228 p. [in Russian].

[9] Harland W.B., Armstrong R.L., Cox A.V., Craig L.E., Smith A.G., Smith D.G. A Geologic Time Scale, 1989 edition: Cambridge University Press; Cambridge. 1990.

[10] Deuser M.J.S., Degens E.T. Carbon isotope fractionation in the system $\mathrm{CO}_{2 \text { (gas) }}-\mathrm{CO}_{2 \text { (aqueos) }}$ $-\mathrm{HCO}_{3}{ }^{-}{ }_{\text {(gas) }}$. Nature 1967. 215: 1033-1037.

[11] Wendt $\mathrm{Y}$., Fractionation of $\mathrm{C}$ isotopes and its temperature dependence in the system $\mathrm{CO}_{2}$ (gas) - $\mathrm{CO}_{2}$ (solution) and $\mathrm{HCO}_{3}{ }^{-}$in solution. Earth Planet Sci. Lett. 1968. 4: 132 147.

[12] Abelson P.H., Hoering T.C. Carbon isotope fractionation in the system $\mathrm{CO}_{2}$ (gas) $\mathrm{CO}_{2}$ (aqua) - $\mathrm{HCO}_{3}{ }^{-}$(aqua). Ann. Rep. Dir. Geophys. Lab 1960. 59: 158-161.

[13] Thode H., Shima M., Rees C., Krishnamurty K. Carbon-13 isotope effects in systems containing carbon dioxide, bicarbonate, carbonate and metal ions. Can. J. Chem. 1965. 43: 582-593.

[14] Ivlev A.A. Chemical Evolution vs Biological Evolution: Coupling Effect and Consequences: Signpost Research Publisher; Kerala. 2013. 79 p.

[15] Popp B.N., Takigiku R, Hayes J.M., Louda J.W., Baker E.W. The post-Paleozoic chronology and mechanism of ${ }^{13} \mathrm{C}$ depletion in primary marine organic matter. Am. J. Sci. 1989. 289: 436-454. 
[16] Hayes J.M., Strauss H., Kaufman A.J. The abundance of ${ }^{13} \mathrm{C}$ in marine organic matter and isotopic fractionation in the global biogeochemical cycle of carbon during the past 800 Ma. Chem. Geol. 1999. 161: 103-125.

[17] Mackenzie F.T., Pigott J.D. Tectonic controls of Phanerozoic sedimentary rock cycling. J. Geol. Soc. London 1981. 138: 183-196.

[18] Nakai N., Jensen M. Biogeochemistry of sulfur isotopes. J. Earth Sci. 1960. 8: 30-35.

[19] Thode H., Monster J., Dunford H. Sulfur isotope geochemistry. Geochim. Cosmochim. Acta 1961. 25: 159-174.

[20] Ivlev A.A., Voronin V.I.Themechanism of carbonisotopefractionationin photosynthesis and carbon dioxide component of the greenhouse effect. Biology Bull. 2007. 34: 603-609.

[21] Kothavala Z., Oglesby R.J., Saltzman B. Sensitivity of equilibrium surface temperature ofCCM3 tosystematicchangesinatmospheric $\mathrm{CO}_{2}$. Geophys. Rev. Lett. 1999. 26: 209-212.

[22] Huang Y., Street-Perrott F.A., Perrott R.A., Meitzger P., Eglinton G. Glacialinterglacial environmental changes inferred from molecular and compound-specific $\delta$ ${ }^{13} \mathrm{C}$ analyses of sediments from Sacred Lake, Mt. Kenya. Geochim. Cosmochim. Acta 1999. 63: 1383-1404.

[23] Bornemann A., Norris R.D., Friedrich O., Britta Beckmann B., Schouten S., Damsté J.S.S., Vogel J., Hofmann P., Wagner T. Isotopic evidence for glaciation during the Cretaceous super greenhouse. Science 2008. 319: 189-192.

[24] Liebermann B.S., Melott A.L. Considering the case for biodiversity cycles: reexamining the evidence for periodicity on the fossil record. PLoS One 2007. 2: e759.

[25] Igamberdiev A.U., Lea P.J. Land plants equilibrate $\mathrm{O}_{2}$ and $\mathrm{CO}_{2}$ concentrations in the atmosphere. Photosynth. Res. 2006. 87: 177-194.

[26] Rothman D.H. Global biodiversity and the ancient carbon cycle. Proc. Natl. Acad. Sci. USA 2001. 98: 4305-4310.

[27] Cornette J.L., Lieberman B.S., Goldstein R.H. Documenting a significant relationship between macroevolutionary origination rate and Phanerozoic $\mathrm{pCO}_{2}$ levels. Proc. Natl. Acad. Sci. USA 2002. 99: 7832-7835.

[28] Bazhenova O.K., Sokolov B.A. Origin of oil is the fundamental problem of natural science. Geologiya Nefti i Gaza. 2002. n 1: 2-8.

[29] Berner R.A., Canfield D.E. A new model for atmospheric oxygen over Phanerozoic time. Am. J. Sci. 1989. 289: 333-361.

[30] VyshemirskiiV.S., Kontorovich A.E. Cycliccharacter of oilaccumulationin Earth history. Geologiya \& Geofizika. 1997. 38: 907-918.

[31] Korchagin V.I. General stratigraphic scale and distribution of oil and gas deposits by stratifications of subdivisions of Phanerozoic and Precambrian. Table composed based on acting stratigraphic lowbook: VNIGNI Publisher; Moscow. 2001. 
[32] Rye R., Holland H.D. Paleosols and the evolution of atmospheric oxygen: a critical review. Am. J. Sci. 1998. 298: 621-672.

[33] Bjerrum C.J., Canfield D.E. New insight into the burial history of organic carbon on the early Earth. Geochim. Geophys. Geosyst. 2004. 5: 1-9.

[34] Canfield D.E., Teske A. Late Proterozoic rise in atmospheric oxygen concentration inferred from phylogenetic and sulphur-isotope studies. Nature 1996. 382: 127-132.

[35] Andrusevich V.E., Engel M.H., Zumberge J.E. Effects of paleolatitude on the stable carbon isotope composition of crude oil. Geology 2000. 28: 847-850.

[36] Andrusevich V.E., Engel M.H., Zumberge J.E., Brothers L.A. Secular, episodic changes in stable carbon isotope composition of crude oils. Chemical Geology 1998. 152: 59-72.

[37] Berner R.A., Petsch S.T., LakeJ.A., Beerling D.J., Popp B.N., Lane R.S., Laws E.A., Westley M.B., Cassar N., Woodward F.I., Quick W.P. Isotope fractionation and atmospheric oxygen: implications for Phanerozoic $\mathrm{O}_{2}$ evolution. Science 2000. 287: 1630-1633.

[38] Berner R.A. The long-term carbon cycle, fossil fuels and atmospheric composition. Nature 2003. 426: 323-326.

[39] Lenton T.M. The role of land plants, phosphorous weathering and fire in the rise and regulation of atmospheric oxygen. Global Change Biol. 2001. 7: 613-629.

[40] Bergman M.J., Lenton T.M., Watson A.G.COPSE: a new model of biogeochemical cycling over Phanerozoic time. Am. J. Sci. 2004. 304: 397-437.

[41] Berner R.A., Kothavala Z. GEOCARB III: a revised model of atmospheric $\mathrm{CO}_{2}$ over Phanerozoic time. Am. J. Sci. 2001. 301: 184-204.

[42] Andre M.J. Modelling ${ }^{18} \mathrm{O}_{2}$ and ${ }^{16} \mathrm{O}_{2}$ unidirectional fluxes in plant: II. Analysis of Rubisco evolution. BioSystems 2011. 103: 251-264.

[43] Tolbert N.E., Benker C., Beck E. The oxygen and carbon dioxide compensation points of $\mathrm{C}_{3}$ plants: possible role in regulating atmospheric oxygen. Proc. Natl. Acad. Sci. 1995. 92: $11230-11233$.

[44] Jahren A.H., Arens N.C., Harbeson S.A. Prediction of atmospheric $\delta^{13} \mathrm{CO}_{2}$ using fossil plant tissues. Rev. Geophys. 2008. 46: 1-12.

[45] Huang Y., Street-Perrott F.A., Metcalfe S.E., Brenner M., Moreland M., Freeman M. Climate change as the dominant control on glacial - interglacial variations in $\mathrm{C}_{3}$ and $\mathrm{C}_{4}$ plant abundance. Science 2001. 293: 1647-1651.

[46] Ratnayake N.P., Suzuki N., Okada M., Takagi M. The variations of stable carbon isotope ratio of land plant-derived n-alkanes in deep-sea sediments from the Bering Sea and the North Pacific Ocean during the last 250000 years. Chem. Geology 2006.228 : 197-208. 
[47] KorteC.,HesselboS.P.Shallow marine carbon and oxygen isotope and elemental records indicate icehouse/greenhouse cycles during Early Jurassic. Paleoceanography 2011. 26: 4219.

[48] Riding J.R., Leng M.J., Kender S., Hesselbo S.P., Feist-Burkhardt S. Isotopic and palynological evidence for a new Early Jurassic environmental perturbation. Paleogeography, Paleoclimatology, Paleoecology 2013. 374: 16-27.

[49] CorsJ., HeimhoferU., Adatte T, Hochuli P.A.,HuckS., Bover-Arnal T. Climaticevolution across oceanic anoxic event 1a derived from terrestrial palynology and clay minerals (Maestrat Basin, Spain). Geol. Mag. 2015. 152: 632-647.

[50] Robinson M., Dowsett H.J., Chandler M.A. Pliocene role in assessing future climate impacts. Eos. 2008. 89: 501-502.

[51] Dwyer G.S., Chandler M.A. Mid-Pliocene sea level and continental ice volume based on coupled benthic $\mathrm{Mg} / \mathrm{Ca}$ palaeotemperatures and oxygen isotopes. Phil. Trans. R. Soc. 2009. A 367: 157-168.

[52] KotthoffU., Greenwood D.R., McCarthy F.M.G., Müller-Navarra K., PraderS., Hesselbo S.P. Late Eocene to middle Miocene (33 to 13 million years ago) vegetation and climate development on the North American Atlantic Coastal Plain (IODP Expedition 313, Site M0027). Clim. Past 2014. 10: 1523-1539. 